\title{
Development of a Green Microwave Assisted Extraction Method for Triazine Herbicides Determination in Soil Samples
}

\author{
Valquíria M. Silva, Willian F. Costa, Jesuí V. Visentainer, \\ Nilson E. Souza and Cláudio C. Oliveira*
}

\author{
Departamento de Química, Universidade Estadual de Maringá, 87020-990 Maringá-PR, Brazil
}

\begin{abstract}
Foi desenvolvido um método de extração limpo, assistido por microondas, para a determinação de herbicidas triazínicos em amostras de solos. A estratégia de extração foi baseada em ambiente micelar associado às microondas, seguido da determinação dos herbicidas por CLAE, de tal forma que o procedimento pudesse ser considerado limpo. Foram utilizadas duas porções $(10 \mathrm{e} 8 \mathrm{~mL})$ da solução extratora de SDS (dodecil sulfato de sódio) 0,06\% (m/v) associada a 0,500 g da amostra e da seguinte programação do forno de microondas: $540 \mathrm{~W}$ (6 min), $0 \mathrm{~W}(1 \mathrm{~min}), 630 \mathrm{~W}$ (2 min). As curvas analíticas apresentaram-se lineares na faixa de 0.05 até $10.0 \mathrm{mg} \mathrm{L}^{-1}$ para atrazina, ametrina e simazina. Os limites de detecção e quantificação foram estimados como $0,90,0,57$ e $0,235 \mu \mathrm{g} \mathrm{g}^{-1}$ e $3,1,1,9$ e $0,8 \mu \mathrm{g} \mathrm{g}^{-1}$ para atrazina, ametrina e simazina, respectivamente. O método proposto é preciso (RSD $<8 \%, \mathrm{n}=3$ ) e os resultados obtidos concordam com aqueles do método clássico. Testes de recuperação dos herbicidas para amostras de solo forneceram valores entre 82,0 e 94,0\%.
\end{abstract}

It was developed a green microwave-assisted extraction method for determination of triazine herbicides in soil samples. The extraction strategy was based on micellar medium associated to microwaves followed by the herbicides determination by HPLC in such way that the procedure could be considered as green. Two portions (10 and $8 \mathrm{~mL}$ ) of aqueous SDS (sodium dodecyl sulphate) $0.06 \%(\mathrm{~m} / \mathrm{v})$ were used as extracting solutions associated to $0.500 \mathrm{~g}$ of sample and the following microwave oven program: $540 \mathrm{~W}(6 \mathrm{~min}), 0 \mathrm{~W}(1 \mathrm{~min}), 630 \mathrm{~W}(2 \mathrm{~min})$. The analytical curves were linear in the analytical range of 0.05 up to $10.0 \mathrm{mg} \mathrm{L}^{-1}$ for atrazine, ametryne and simazine. The limits of detection and quantification were estimated as $0.90,0.57$ and $0.235 \mu \mathrm{g} \mathrm{g}^{-1}$ and $3.1,1.9$ and $0.8 \mu \mathrm{g} \mathrm{g}^{-1}$ for atrazine, ametryne and simazine, respectively. The proposed method is precise ( $\mathrm{RSD}<8 \%, \mathrm{n}=3$ ) and the obtained results are in agreement with the classical one. Recovery tests for soil samples indicated that the percentage of recuperation were between 82.0 e $94.0 \%$.

Keywords: triazines, microwave digestion, green extraction method, HPLC

\section{Introduction}

Triazenes are chemical synthetic herbicides used in several cultures to control the presence of broad-leaved and grassy weeds. Their use is common in sugarcane, corn, cocoa bean, coffee and banana cultures. ${ }^{1}$ The triazines action mechanism is via photosynthetic inhibition, ${ }^{2}$ and for this reason, should be toxic only for plants but, there are experimental evidences that these compounds can affect the ecosystem, including the human health. ${ }^{3}$

Considering the worldwide use of triazines and their potential contamination risk, several regulators agencies have established limits for concentration of

*e-mail: ccoliveira@uem.br these compounds in the soil, water and foods. ${ }^{2,4}$ Thus, it is fundamental to have analytical methods able to do the triazines determination.

Due to the environmental and health interests and, considering that triazine herbicides represent $30 \%$ of all herbicides used in the world ${ }^{1}$ and is the second herbicide most frequent in Brazil, the determination of triazines compounds is important and, for these reasons, several analytical methodologies have been developed for determination of these substances in food, soil, sediments and plants. ${ }^{5-7}$ Normally, these methods involve the extraction of the triazines compounds from the sample by using an organic solvent, followed by a step to do the analytes concentration, mainly due to the low concentration of these chemical species in most samples and, to minimize 
the presence of interferant species that could impair the analytical signal measurements.

The most utilized analytical extraction procedures for triazines compounds are: liquid-liquid, ${ }^{8}$ Soxlet, ${ }^{9}$ liquidsolid ${ }^{10}$ and solid phase extraction. ${ }^{4}$ These procedures, normally, are lagging and increase the possibility to introduce errors in the analysis. Furthermore, all the previous mentioned procedures utilize organic solvents during the extraction or elution steps, which will generate chemical residues of hard treatment, consuming time and money and, open the possibility to more environmental contaminations. Finally, the analytical methods that exploit these strategies cannot be considered green and are not in agreement with the actual tendency to develop green analytical methods. ${ }^{11}$

The usage of microwave energy for sample preparation has been increased in the last years ${ }^{12-14}$ mainly due to the heating mechanism, which helps to decrease the time necessary to digest the sample matrix or to do analyte extraction and consumes lower amount of solvent. ${ }^{13}$ For these reasons, there are in the literature some analytical methods that exploit the microwave to do the extraction of triazines herbicides, ${ }^{15}$ organphosphorous ${ }^{16}$ and organochlorine ${ }^{17}$ pesticides in soil and food samples. Some of these procedures exploit the utilization of aqueous surfactant solutions as solvent, ${ }^{15}$ taking advance of the microwave interaction be more effective with polar molecules. ${ }^{18}$

Considering that the microwave assisted extraction procedure associated to micellar medium can decrease or eliminate the utilization of organic solvent in the extraction steps with advances related to time and cost, the aim of the present work is to develop a green extraction method to do the determination of simazine, atrazine and ametryne in soil samples exploiting this strategy. It should be emphasized that the HPLC method utilized here was developed by our research group and also exploits the micellar medium. Thus, the extraction procedure and the HPLC analytical method utilized in the present work can be considered as green.

\section{Experimental}

\section{Reagent and solutions}

The herbicides standard stock solutions were prepared dissolving $100.0 \mathrm{mg}$ of simazine, atrazine and ametryne, respectively, from EPA-Research Thiangle Park standard (USA) in methanol (HPLC-grade from Merck, Germany) and completing the volume up to $1000 \mathrm{~mL}$ in a volumetric flask. These solutions were stable for at least 1 month when stored in the dark at $4{ }^{\circ} \mathrm{C}$. Working solutions were prepared from the stock solutions by appropriate dilution with ethanol (HPLCgrade from Merck, Germany).

The aqueous SDS solutions (0.03, 0.06 and 0.08, 0.10 and $0.25 \%(\mathrm{~m} / \mathrm{v}))$ were prepared dissolving appropriated amount of SDS (from Sigma, St. Louis, USA) in high-purity deionized water.

The mobile phase was prepared dissolving $22.25 \mathrm{~g}$ of SDS and $250.0 \mathrm{~mL}$ of ethylic alcohol in $600 \mathrm{~mL}$ of $0.1 \mathrm{~mol} \mathrm{~L}^{-1}$ of sodium phosphate plus $50.0 \mathrm{mmol} \mathrm{L}^{-1}$ of ammonium chloride solution and adjusting the $\mathrm{pH}$ to 7.0 with $\mathrm{NaOH}$ or $\mathrm{HCl} 0.1 \mathrm{~mol} \mathrm{~L}^{-1}$. The volume was completed with the saline solution up to $1000 \mathrm{~mL}$ and, the solution was passed, before use, through a $0.45 \mu \mathrm{m}$ membrane filter.

\section{Equipments}

Chromatographic separation using the green analytical method was carried out using a Varian ProStar System with Star Chromatography Workstation and LC control software (Varian Analytical Instruments) comprising a ProStar 240 solvent delivery modules, a Model ProStar 410 AutoSampler with a sample loop of $100 \mu \mathrm{L}$, a Model ProStar 330 photodiode array detector with the Polyview $2000^{\mathrm{TM}}$ program and a microsorb C18 $250 \times 4.6 \mathrm{~mm}$ column with particles of $5 \mu \mathrm{m}$ equipped with a microsorb $\mathrm{C} 1810 \times 4 \mathrm{~mm}$ guard column. All the experiments were conducted at $25{ }^{\circ} \mathrm{C}$. Before analysis, the column was conditioned making the mobile phase flows through the system for $20 \mathrm{~min}$ at $1.0 \mathrm{~mL} \mathrm{~min}{ }^{-1}$. For chromatographic separation it was injected $20 \mu \mathrm{L}$ of the sample extract, the mobile phase was kept isocratic, at $0.6 \mathrm{~mL} \mathrm{~min}^{-1}$ and the acquisition of the data were done at $222 \mathrm{~nm}$.

A $900 \mathrm{~W}$ microwave oven (Electrolux, Brazil) associated to PTFE extraction flask $(30 \mathrm{~mL})$ was used to extraction procedures.

A $\mathrm{pH}$-meter was used for the characterization of the soil samples.

\section{Samples}

Four soil samples were collected from the surface of (0-20 cm depth) in different farm cultivating different cultures in the region of Maringá, Paraná, Brazil. The soils samples were bring to the laboratory sand were dried at $60{ }^{\circ} \mathrm{C}$ for $48 \mathrm{~h}$, pulverized and sieved $(<2.0 \mathrm{~mm})$.

\section{Soil characterization}

The main chemical ( $\mathrm{pH}$ in $\mathrm{H}_{2} \mathrm{O}$ extract, $\mathrm{pH}$ in $\mathrm{CaCl}_{2}$ extract, $\mathrm{Ca}^{2+}, \mathrm{Mg}^{2+}, \mathrm{K}^{+}, \mathrm{H}^{+}+\mathrm{Al}^{3+}, \mathrm{Al}^{3+}$, Total of $\mathrm{P}$ and $\mathrm{C}$ ) and physical (\% of clay, sand and silt) characteristics of 
the soil samples were determined (Table 1) following the IAPAR recommendations. ${ }^{19}$ The atrazine, simazine and ametryne contents were determined in the soil sample by using a traditional analytical procedure ${ }^{1}$ that uses dichloromethane and acetone as extraction solvents and a RP18 column and a gradient between aqueous ammonium solution and acetonitrile as stationary and mobile phase, respectively.

Table 1. Chemical and physical characteristics of the spiked soil sample chosen to optimization of the extraction process

\begin{tabular}{lc}
\hline Parameters & Determined values* \\
\hline $\mathrm{pH}\left(\mathrm{H}_{2} \mathrm{O}\right)$ & 6.23 \\
$\mathrm{pH}\left(\mathrm{CaCl}_{2}\right)$ & 5.30 \\
$\mathrm{Ca}^{2+}\left(\mathrm{mmol} \mathrm{L}^{-1}\right)$ & 0.848 \\
$\mathrm{Mg}^{2+}\left(\mathrm{mmol} \mathrm{L}^{-1}\right)$ & 0.18 \\
$\mathrm{~K}^{+}\left(\mathrm{mmol} \mathrm{L}^{-1}\right)$ & 0.093 \\
$\mathrm{H}^{+}+\mathrm{Al}^{3+}\left(\mathrm{mmol} \mathrm{L}^{-1}\right)$ & 0.339 \\
$\mathrm{Al}^{3+}\left(\mathrm{mmol} \mathrm{L}^{-1}\right)$ & $\mathrm{nd}$ \\
$\mathrm{P}\left(\mathrm{mg} \mathrm{L}^{-1}\right)$ & 9.68 \\
$\mathrm{C}\left(\mathrm{mg} \mathrm{L}^{-1}\right)$ & 2.26 \\
$\mathrm{Clay}(\%)$ & 83.0 \\
Sand $(\%)$ & 34.1 \\
Silt $(\%)$ & 9.20 \\
\hline
\end{tabular}

*Mean values for three replicates. nd $=$ not detected.

\section{Preparation of spiked soil samples}

Preliminary studies to evaluate the main variables (microwave oven potency, composition of the extraction solution, time interval and sample amount) in the microwave assisted extraction procedure were carried out by using a spiked soil sample. For the task, a soil sample with high carbon total content and without the presence of triazines compounds were selected.

To $20.0 \mathrm{~g}$ of dried soil it was added $25.0 \mathrm{~mL}$ of a standard solution containing $20.0 \mathrm{mg} \mathrm{L}^{-1}$ of each herbicide in methanol (simazine, atrazine and ametryne). The suspension was homogenized and let to dry at ambient temperature $\left(25^{\circ} \mathrm{C}\right)$. The final soil contains $25 \mu \mathrm{g} \mathrm{g}^{-1}$ of each herbicide was keep in the refrigerator until its utilization in the extraction procedures.

\section{Optimization of the microwave assisted extraction procedure}

Different aliquots of the spiked soil were weighed $(0.5,1.0$ and $2.0 \mathrm{~g})$ and transferred to the PTFE extraction vessels ( $30 \mathrm{~mL}$ of capacity). The volume of the extraction solution was kept constant $(10 \mathrm{~mL})$ to avoid high pressure into the extraction vessel and; it was used as extraction solution ethanol/water at 1.0, 2.0, 5.0 and $7.0 \%(\mathrm{v} / \mathrm{v})$ and aqueous SDS solution at different concentrations $(0.03$, 0.06 and $0.08,0.10$ and $0.25 \%(\mathrm{~m} / \mathrm{v}))$. After suspension homogenization, the extraction vessels were closed and put into the microwave oven and a program sequence of power was carried out. After cooling, the extract was filtered through a $0.45 \mu \mathrm{m}$ membrane filter, the extraction vessel was wash with $6.0 \mathrm{~mL}$ of the extraction solution that was also filtered in the same membrane and both solutions were transferred to volumetric flask and, the volume was completed up to $25 \mathrm{~mL}$. This extract was injected in the chromatograph without further extract purification.

After the selection of the better extraction conditions, the optimized extraction condition was applied to simazine, atrazine and ametryne determination in the soil samples.

\section{Method calibration, validation and sample analysis}

For quantitative analysis of the soil samples external calibration was used plotting peak area (y) versus injected amount of the herbicides $(0.0,0.05,0.25,0.50,1.00,2.0$, 5.00 and $10.00 \mathrm{mg} \mathrm{L}^{-1}$ ). The calibration curves were used to determine the analyte concentrations in the soil samples and in the free herbicide soil test sample with and without spiking. The LODs and LOQs $(n=6)$ were estimated by using a signal-to-noise ratio of 3 and 10, respectively, and processing the analysis (including extraction step) of a soil test sample containing only the herbicides.

The method validation was carried out spiking the test sample with herbicides at three different concentration levels before carried the microwave assisted extraction procedure and, analyzing the extracts three times. The soil samples were too analyzed by using the proposed microwave assisted extraction and HPLC methods and the results were compared to those obtained by the traditional procedure. ${ }^{1}$

\section{Results and Discussion}

\section{Selection of the analytical method}

Considering that atrazine, ametryne and simazine have the same basic structure (Figure 1), the molecules present similar eletronic transition in the UV region of the spectrum, which became very hard to do the spectrophotometric determination of these compounds without addition of separation steps before the measurement of the analytical signal. Furthermore, is a reality the necessity for determination of these herbicides in soil samples that present high concentration of organic matter, which can 
introduce errors in the analysis; as normally, the organic matter absorbs electromagnetic radiation in the UV region. In this way, a selection of an analytical method able to determine multi-components is imperative. Thus, the HPLC was chosen as analytical technique.
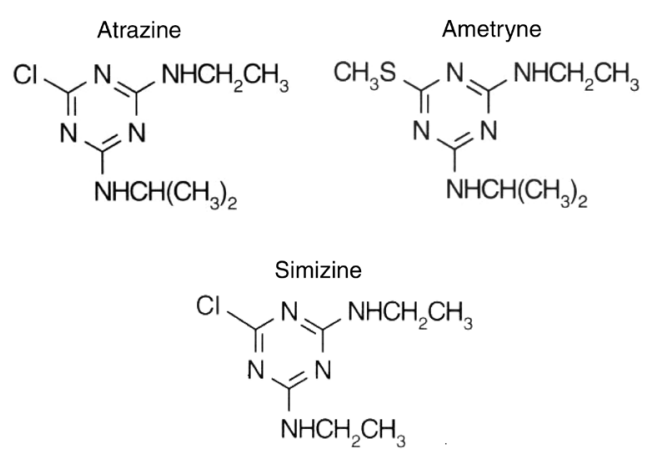

Figure 1. Strutures of the triazines herbicides. Atrazine, Ametryne and Simizine.

As chromatographic method was elected to determine the herbicides and, normally this analytical technique is associated to the utilization of organic solvents as mobile phase, which do not permit to classify the final methodology as green, the objective of the present work was to develop a green microwave assisted extraction and carried out the analytical measurements following the same principle. To avoid the common usage of organic solvent as mobile phase, a surfactant was utilized to vary the polarity of the water and to change the characteristics of the $\mathrm{C} 18$ chromatographic column in the way that the affinity of the low polar triazines compounds by the mobile phase could be increased and, at the same time, the column could become more polar due to the adsorption of the SDS, ${ }^{20}$ permitting the elution of atrazine, ametryne and simazine by an hydroalcoholic SDS solution. The used mobile phase was constituted of SDS $2.25 \%(\mathrm{~m} / \mathrm{v})$, ethanol $25.0 \%$ $(\mathrm{v} / \mathrm{v}), 0.10 \mathrm{~mol} \mathrm{~L}^{-1}$ sodium phosphate and ammonium chloride $50.0 \mathrm{mmol} \mathrm{L}^{-1}$ at $\mathrm{pH} 7.0$ associated at a flow rate of $0.60 \mathrm{~mL} \mathrm{~min}^{-1}$. It should be stressed that each mobile phase component presents a special function: SDS - permits the formation of the micellar medium and stationary phase modification; ethanol - decrease the amount of surfactant adsorbed in the $\mathrm{C} 18$ phase improving the analytes diffusion between the mobile and stationary phase; ammonium - help in the micelles formation decreasing the repulsion between the negative charges and phosphate buffer solution permits the $\mathrm{pH}$ control.

Under these conditions, the atrazine, ametryne and simaze were separated in only $30 \mathrm{~min}$ with chromatographic resolution adequate to quantitative determinations (Figure 2) and using a mobile phase presenting low toxicity as the surfactant SDS and the ethanol are biodegradable. In the chromatogram there are good separation between peaks (Figure 2), which can indicate that the total running time could be improved, but due to the presence of high viscosity ethanol in the mobile phase, the flow rate or the amount of alcohol in the mobile phase could not be increase at will due to the high system backpressure and, for this reason, the running time cannot be decreased.

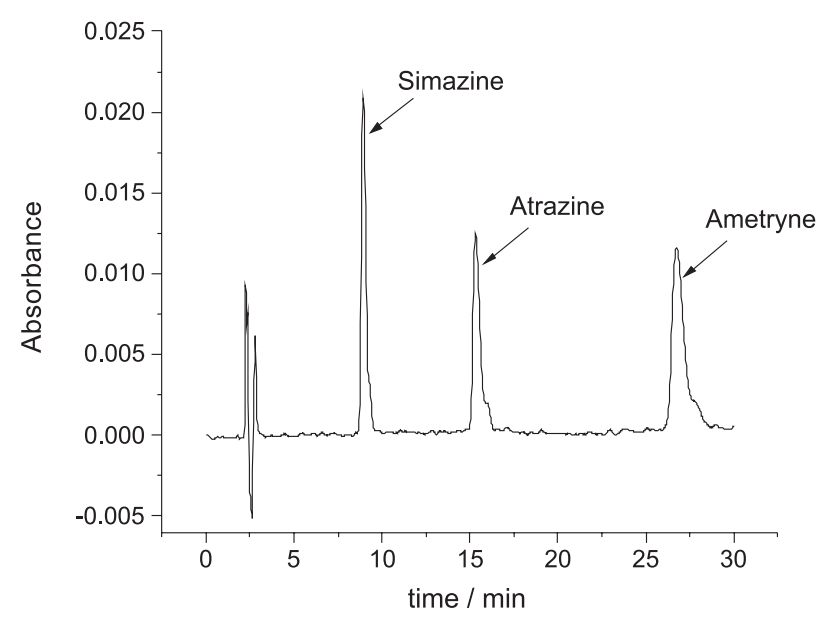

Figure 2. Chromatogram of standard solutions containing atrazine, ametryne and simazine. Data obtained for concentrations of $10 \mathrm{mg} \mathrm{L}^{-1}$ for each herbicide, mobile phase flow rate of $0.6 \mathrm{~mL} \mathrm{~min} \mathrm{~m}^{-1}$ containing $0.05 \mathrm{~mol} \mathrm{~L}^{-1}\left[\mathrm{NH}_{4} \mathrm{Cl}\right], 2.25 \%(\mathrm{~m} / \mathrm{v})[\mathrm{SDS}], 25 \%$ (v/v) EtOH and $0.1 \mathrm{~mol} \mathrm{~L}^{-1}$ phosphate buffer at $\mathrm{pH} 7$, and injection volume of $20 \mu \mathrm{L}$.

\section{Optimization of the microwave assisted extraction procedure}

Based on the chemical and physical characteristics of the collected soil samples it was selected a soil sample with high clay and organic matter content and without the presence of triazines herbicides (Table 1) to be spiked with the herbicides and utilized in the optimization of the extraction procedure, because the adsorption of triazines in the soil occurs mainly due to the presence of organic matter ${ }^{15}$ and clay content. ${ }^{1}$ The organic matter is responsible by the low polarity groups that present high affinity by the triazines and the clay is responsible by the small particles that have high superficial area where the triazines can be absorbed. Thus, selected soil sample used to carry out the optimization of the extracting procedure can retain more effectively the herbicides, which becomes the extraction process more difficult.

Considering that there was information in the literature about the extraction of herbicides assisted by microwave utilizing only water as extracting solution, ${ }^{15}$ initially this possibility was taken into account, as at high temperature the water dielectric constant decrease and the solvent become less polar, which increase its affinity by the simazine, atrazine and ametryne. However, it was noted that although the occurrence of the herbicide extraction 
at high temperature, after the extraction process it is necessary to taken the digestion vessel to comeback to ambient temperature to decrease the internal pressure and to be possible to open it and collected the extracts, but at ambient temperature the water dielectric constant comes to be high, which decreases its affinity by the herbicides and lead to precipitation of the analytes or re-absorption by the solid particles, mainly for samples with high herbicide concentrations. Thus, it was decided to evaluate hydroethanolic solutions as extracting agent.

For extracting the herbicides from the spiked soil using hydroethanolic solutions as extractor the following microwave oven program was carried out: $6 \mathrm{~min}$ at $530 \mathrm{~W}$, $1 \mathrm{~min}$ at $0 \mathrm{~W}, 2$ min to $630 \mathrm{~W}$; the mass of sample was varied from 0.500 up to $2.000 \mathrm{~g}$, the volume of the extracting solution was fixed as $10.0 \mathrm{~mL}$ due to the digestion vessel capacity, and the ethanol concentrations ranged from 1.0 up to $7 \%(\mathrm{v} / \mathrm{v})$. Under these conditions the obtained analytes recoveries using as extractor hydroalcoholic solutions (1, 2,5 and $7 \%$ (v/v) of ethanol) were only $62.5 \pm 4.3,41.6$ $\pm 8.9,63.0 \pm 8.5$ and $42.1 \pm 12.7$, respectively; which did not permit to do a relationship between concentration of alcohol in the extraction solution and amount of herbicides extracted. For this reason, aqueous SDS solutions were tested as extraction medium.

With the objective to improve the herbicide extraction efficiency, aqueous solutions of SDS were used as extractors. It should be stressed that the SDS is one of the components of the mobile phase in the chromatographic method used to determine atrazine, ametryne and simazine and is biodegradable.

For experiments utilizing the former microwave program, $0.500,1.000$ and $2.000 \mathrm{~g}$ of soil sample and SDS solutions at concentrations of 0.03, 0.06, 0.08, 0.10 and $0.25 \%(\mathrm{~m} / \mathrm{v})$ it was observed that the better results were obtained for $0.500 \mathrm{~g}$ of soil sample and $0.06 \%$ SDS solution with medium values for extraction efficiencies of $49.11 \pm 5.74,53.70 \pm 5.20,23.63 \pm 5.40 \%$ for simazine, atrazine and ametryne, respectively.

It was a surprise result the $0.06 \%$ SDS extraction solution be more effective in the herbicides extraction; as it was waited that the solution at critical micellar concentration $(0.25 \%(\mathrm{~m} / \mathrm{v}))$ could be give better results due to the presence of the micelles that could increase the solubility of the herbicides in the extracting solution with consequent better extraction efficiency. The obtained results probably are associated to the fact that the addition of surfactant to water decrease the superficial tension and the viscosity of the solvent, which help the solvent penetration in the soil particles, increasing the transference of mass between the soil and the extractor due to the weakening of the interaction between herbicide/soil and assisting in the herbicide liberation to the extraction solution.

As microwave oven power and time interval could not be increased at will due to the possibility of analytes degradation by the establishment of high temperature and pressure into the digestion vessel, it was verified the possibility of the low extraction efficiency be related to the saturation of extraction solution. Thus, the herbicides concentration in the soil sample was decreased to $8.33 \mu \mathrm{g} \mathrm{g}^{-1}$ ( $1 / 3$ of the initial value) and the extraction procedure was repeated. For this condition the extraction efficiencies of the herbicides $(52.6 \pm 0.4,69.7 \pm 3.9,20.9 \pm 3.1$, for simazine, atrazine and ametryne, respectively) values that are not much better than those obtained when the herbicides concentration was three times higher; indicating that the reason for the low extraction efficiencies was not the saturation of the extraction solution but probably the energy involved during the extraction process that could not be sufficient to obtain quantitative results.

As time interval and microwave power could not be increased and taken into account that the efficiency of the extraction process can increase with the number of extractions, a second cycle of the extraction process was added. Thus, $0.500 \mathrm{~g}$ of spiked soil sample $\left(25 \mu \mathrm{g} \mathrm{g}^{-1}\right.$ of each herbicide) plus $10 \mathrm{~mL}$ of the $0.06 \%(\mathrm{~m} / \mathrm{v})$ SDS extraction solution were submitted to microwave action ( $6 \mathrm{~min}$ at $530 \mathrm{~W}, 1 \mathrm{~min}$ at $0 \mathrm{~W}, 2 \mathrm{~min}$ to $630 \mathrm{~W}$ ). After cooling, the extract was separated and another $8 \mathrm{~mL}$ of the extraction solution were added to the solid and, the suspension was submitted to another extraction cycle in the microwave oven under the same former program sequence. This second portion of the extract was joined to the first one, the digestion vessel was washed with the SDS extracting solution $(6 \mathrm{~mL})$ and the volume was completed up to $25 \mathrm{~mL}$.

Under these conditions the extraction efficiency improved for all herbicides (Table 2) with values 82.0 to $94.0 \%$, in this way, this extraction sequence was considered adequate to be applied to the soil samples.

\section{Method calibration, validation and sample analysis}

The extraction procedure its takes approximately 18 min to carried out the extraction of the three herbicides in six soil sample (the capacity of digestion vessels into microwave oven) consuming $10.8 \mathrm{mg}$ of SDS per sample, which permits to classify as green.

The green chromatographic method used to determine atrazine, ametryne and simazine is soil extracts is able to run one sample in $30 \mathrm{~min}$ with all peak resolutions higher than two (Figure 2), consuming $405 \mathrm{mg}$ of SDS and $7.5 \mathrm{~mL}$ 
Table 2. Extraction recoveries for soil spiked sample $\left(25.0 \mu \mathrm{g} \mathrm{g}^{-1}\right)$ utilizing $0.06 \%(\mathrm{~m} / \mathrm{v})$ SDS as extracting solution. Data were obtained for the following conditions: $0.500 \mathrm{~g}$ of soil sample, two extraction (with 10 and $8 \mathrm{~mL}$ ) and microwave oven program of $6 \mathrm{~min}$ at $540 \mathrm{~W}, 1 \mathrm{~min}$ at $0 \mathrm{~W}$ and $2 \mathrm{~min}$ at $630 \mathrm{~W}(\mathrm{n}=3)$. The consumed reagents referred only to the extraction step

\begin{tabular}{lccc}
\hline & Herbicide & $\begin{array}{c}\text { Microwave } \\
\text { extraction }\end{array}$ & $\begin{array}{c}\text { Conventional } \\
\text { extraction }\end{array}$ \\
\hline Recoveries \pm RSD & Simazine & $81.02 \pm 0.93$ & $77.08 \pm 2.50$ \\
& Atrazine & $93.73 \pm 4.77$ & $65.70 \pm 0.80$ \\
& Ametryne & $82.21 \pm 8.61$ & $*$ \\
time interval & & $18 \mathrm{~min}$ & $210 \mathrm{~min}$ \\
elapsed for & & & \\
extraction & & $0.06 \%(\mathrm{~m} / \mathrm{v})$ & $\begin{array}{c}\text { dichloromethan/ } \\
\text { propanone/ } \\
\text { methanol/ } \\
\text { Chemicals }\end{array}$ \\
used & & $\mathrm{SDS}$ & $\begin{array}{c}\text { michloromethane } \\
\text { trich }\end{array}$ \\
\hline
\end{tabular}

*It was not possible to calculate due to the co-elution of interferences.

of ethanol, a biofuel produced in large scale in Brazil by fermentation of sugarcane.

The analytical curves were linear in the analytical range of 0.05 up to $10.0 \mathrm{mg} \mathrm{L}^{-1}$ for atrazine, ametryne and simazine; and presented the following linear equations: area $=-9091+5207200$ [atrazine], $\mathrm{R}^{2}=0.9993 ;$ area $=-490344+410344$ [ametryne], $\mathrm{R}^{2}=0.9997$ and area $=-961588+9378190$ [simazine], $\mathrm{R}^{2}=0.9991$ and, the limits of detection for atrazine, ametryne and simazine were estimated in a test soil sample as 0.90 , 0.57 and $0.235 \mu \mathrm{g} \mathrm{g}{ }^{-1}$, respectively, whereas the limit of quantification were estimated as $3.1,1.9$ and $0.8 \mu \mathrm{g} \mathrm{g}^{-1}$ for atrazine, ametryne and simazine.

When the proposed method was applied to a soil sample free of atrazine, ametryne and simazine with and without addition of the herbicides it was possible to observe that any interference in the herbicides peaks occurs in the presence of the sample matrix (Figure 3).

The precision of the method was always better than $8 \%$ (Tables 2 and 3 ) and, when different soil samples were analyzed by the proposed method the results presented good recoveries. When it was possible to compare the obtained

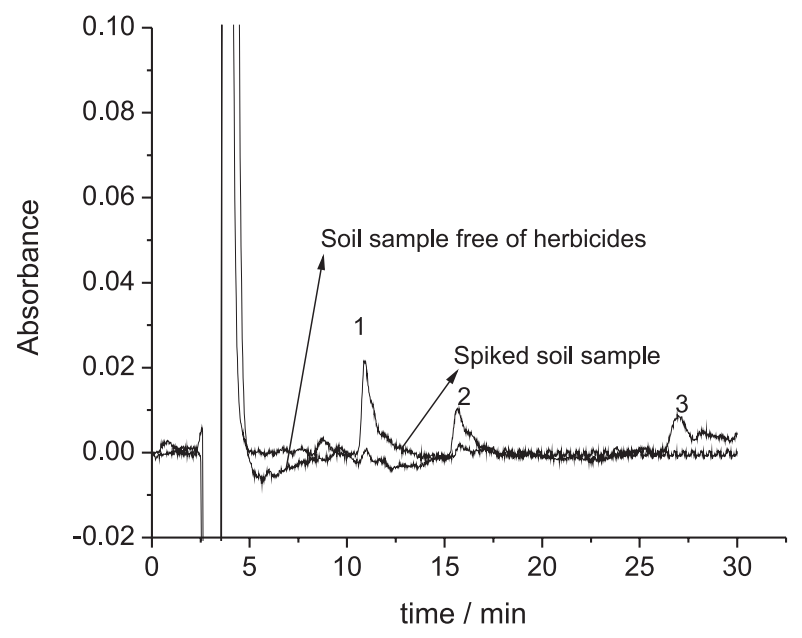

Figure 3. Chromatogram of a test soil sample with and without the herbicides addition. Data obtained after extraction of $0.500 \mathrm{~g}$ of soil spiked with $25 \mu \mathrm{g} \mathrm{g}^{-1}$ and using 10 and $8 \mathrm{~mL}$ of extracting solution $(0.06 \%(\mathrm{~m} / \mathrm{v})$ SDS). The chromatographic conditions were mobile phase flow rate of 0.6

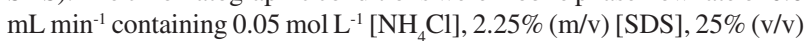
EtOH and $0.1 \mathrm{~mol} \mathrm{~L}^{-1}$ phosphate buffer at $\mathrm{pH} 7$, and injection volume of $20 \mu \mathrm{L}$. (1) simazine, (2) atrazine and (3) ametryne.

results by the proposed method with those obtained by using the traditional one, that uses organic solvents as extraction solution and chromatographic mobile phase, ${ }^{1}$ the data were in agreement (Table 3). Due to the high content of organic matter in the analyzed soil samples it was noted the co-elution of some interferant species together with the ametryne peak in the traditional method, which did not permit the analyte determination by using the conventional chromatographic method.

\section{Conclusions}

It is possible to do the microwave assisted extraction and posterior chromatographic determination of the triazine herbicides atrazine, ametryne and simazine in soil samples using SDS solutions as extractor and 2.25\% $(\mathrm{m} / \mathrm{v}) \mathrm{SDS}, 25.0 \%(\mathrm{v} / \mathrm{v})$ ethanol, $0.10 \mathrm{~mol} \mathrm{~L}^{-1}$ sodium phosphate and $50.0 \mathrm{mmol} \mathrm{L}^{-1}$ ammonium chloride at pH 7.0 as mobile phase.

The procedures are simple, robust, precise and present analytical frequency superior to the conventional ones,

Table 3. Determination of herbicides in soil samples by the proposed green method and by the conventional one. The results are expressed in $\mu g \mathrm{~g}^{-1} \pm \mathrm{RSD}$

\begin{tabular}{lcccccc}
\hline Samples & \multicolumn{3}{c}{ Proposed Method } & & \multicolumn{3}{c}{ Conventional Method } \\
& Atrazine & Ametryne & Simazine & Atrazine & Ametryne & Simazine \\
\hline Soil 1 & $3.76 \pm 0.05$ & $5.04 \pm 0.3$ & $4.86 \pm 0.04$ & $3.3 \pm 0.1$ & $*$ & $3.1 \pm 0.1$ \\
Soil 2 & $5.70 \pm 0.2$ & $5.04 \pm 0.1$ & $4.86 \pm 0.06$ & $5.1 \pm 0.5$ & $*$ & $4.7 \pm 0.4$ \\
Soil 3 & $7.70 \pm 0.3$ & nd & nd & $7.4 \pm 0.4$ & nd & nd \\
\hline
\end{tabular}

*It was not possible to calculate the peak area due to the presence of interferant; nd = not detected. 
mainly due to the analite extraction step and, can be considered as green.

\section{Acknowledgments}

The support of Fundação Araucária, CAPES and CNPq are greatly appreciated.

\section{References}

1. Pacakova, V.; Stulik, K.; Jiskra, J.; J. Chromatogr., A 1996, 754, 17.

2. Dean, J. R.; Wade, G.; Barnabas, I. J.; J. Chromatogr., A 1996, 733, 295.

3. Sabik, H.; Cooper, S.; Lafrance, P.; Fournier, J.; Talanta 1995 , $42,717$.

4. BRASIL, Ministério da Saúde; Portaria 518, 25 março de 2004; Brasília, 2004. http://189.28.128.179:8080/518/legislacoes/ portaria-ms-no.-518.

5. Dagnac, T.; Bristeau, A.; Jeannot, R.; Mouvet, C.; Baranb, N.; J. Chromatogr., A 2005, 1067, 225.

6. Shen, G.; Lee, H. K.; J. Chromatogr., A 2003, 985, 167.

7. Lopes-Avila, V.; Hitara, P.; Kraska, S.; Flanagan, M.; Taylor Jr, J. H.; Anal. Chem. 1985, 57, 2797.

8. Almed, F. E.; Trends Anal. Chem. 2001, 20, 649.

9. Sain, N.; Dean, J. R.; Abdullah, M. P.; Zakaria, Z.; J. Chromatogr., A 1997, 791, 361.
10. Tadeu, J. L.; Sanches-Brunete, C.; Perez, R. A.; Fernandez, M. D.; J. Chromatogr., A 2000, 882, 175.

11. Kienen, V.; Costa, W. F.; Visentainer, J. V.; Souza, N. E.; Oliveira, C. C.; Talanta 2008, 75, 141.

12. Burguera,J.L.; Burguera, M.; Carrero, P.; Rivas, C.; Gallignani, M.; Brunetto, M. R.; Anal. Chim. Acta 1995, 308, 349.

13. Oliveira, C. C.; Sartini, R. P.; Zagatto, E. A. G.; Anal. Chim. Acta 2000, 413, 41.

14. Serrrano, A.; Gallego, M.; J. Chromatogr., A 2006, 1104, 323.

15. Xiong, G.; Tang, B.; He, X.; Zhao, M.; Zhang, Z.; Zhang, Z.; Talanta 1999, 48, 333.

16. Pedrón-Sanz, C.; Halko, R.; Ferrera, Z. S.; Rodríguez, J. J. S.; J. Chromatogr., A 2005, 1078, 13.

17. Moreno, D. V.; Ferrera, Z. S.; Rodríguez, J. J. S.; Anal. Chim. Acta 2006, 571, 51.

18. Lorentzen, E. M. L.; Kingston, H. M.; Anal. Chem. 1996, 68, 4316.

19. Pavan, M. A.; Bloch, M. F.; Zempulski, H. C.; Miyazawa, M.; Zocoler, D. C.; Manual de Análise de Solo e Controle de Qualidade, Instituto Agronômico do Paraná-IAPAR: Circular $\mathrm{n}^{\circ}$ 76, Londrina, 1992.

20. Vidotti, E. C.; Costa, W. F.; Oliveira, C. C.; Talanta 2006, 68, 516.

Received: July 9, 2009

Web Release Date: March 4, 2010 